Correction

\title{
Correction: Hauck et al. Molecular Orbital Theory-Teaching a Difficult Chemistry Topic Using a CSCL Approach in a First-Year University Course. Educ. Sci. 2021, 11, 485
}

\author{
David Johannes Hauck, Insa Melle * and Andreas Steffen
}

Citation: Hauck, D.J.; Melle, I.;

Steffen, A. Correction: Hauck et al. Molecular Orbital Theory-Teaching a Difficult Chemistry Topic Using a CSCL Approach in a First-Year University Course. Educ. Sci. 2021, 11, 485. Educ. Sci. 2022, 12, 117. https://doi.org/10.3390/ educsci12020117

Received: 23 December 2021 Accepted: 24 December 2021 Published: 10 February 2022

Publisher's Note: MDPI stays neutral with regard to jurisdictional claims in published maps and institutional affiliations.

Copyright: (C) 2022 by the authors. Licensee MDPI, Basel, Switzerland. This article is an open access article distributed under the terms and conditions of the Creative Commons Attribution (CC BY) license (https:// creativecommons.org/licenses/by/ $4.0 /)$.
Faculty of Chemistry and Chemical Biology, TU Dortmund University, Otto-Hahn-Straße 6, 44227 Dortmund, Germany; david.hauck@tu-dortmund.de (D.J.H.); andreas.steffen@tu-dortmund.de (A.S.)

* Correspondence: insa.melle@tu-dortmund.de

\section{Addition of an Author}

Andreas Steffen was not included as an author in the original publication [1]. The corrected Author Contributions Statement appears here. The authors apologize for any inconvenience caused, and state that the scientific conclusions are unaffected. The original publication has also been updated.

\section{Insert New Author Contributions Statement}

Conceptualization, D.J.H., I.M. and A.S.; methodology, D.J.H. and I.M.; software, D.J.H.; validation, D.J.H., I.M. and A.S.; formal analysis, D.J.H. and I.M.; investigation, D.J.H.; resources, I.M. and A.S.; data curation, D.J.H.; writing-original draft preparation, D.J.H. and I.M.; writing—review and editing, D.J.H. and I.M.; visualization, D.J.H.; supervision, I.M. and A.S.; project administration, D.J.H. and I.M.; funding acquisition, I.M. All authors have read and agreed to the published version of the manuscript.

\section{Reference}

1. Hauck, D.J.; Melle, I.; Steffen, A. Molecular Orbital Theory-Teaching a Difficult Chemistry Topic Using a CSCL Approach in a First-Year University Course. Educ. Sci. 2021, 11, 485. [CrossRef] 